\title{
Cigarette Smoker
}

National Cancer Institute

\section{Source}

National Cancer Institute. Cigarette Smoker. NCI Thesaurus. Code C17949.

An individual who currently, or recently, smokes cigarettes regularly. 